\title{
Influence of Linseed and Fish Oil on Metabolic and Immunological Indicators of Laying Hens
}

\author{
M. ŠVEDOVÁ ${ }^{1}$, L. VAŠKO ${ }^{1}$, A. TREBUNOVÁ ${ }^{1}$, R. KAŠTEL ${ }^{1}$, M. TUČKOVÁ ${ }^{2}$, M. ČERTÍK ${ }^{3}$ \\ ${ }^{1}$ Department of Chemistry, Biology, and Biochemistry, \\ ${ }_{2}^{2}{ }^{\text {st }}$ Internal Clinic, University of Veterinary Medicine in Košice, Slovak Republic \\ ${ }^{3}$ Slovak University of Technology, Faculty of Chemical and Food Technology, Department of Biochemical \\ Technology, Bratislava, Slovak Republic \\ Received March 5, 2007 \\ Accepted November 15, 2007
}

\begin{abstract}
Švedová M., L. Vaško, A. Trebunová, R. Kaštel’, M. Tučková, M. Čertík: Influence of Linseed and Fish Oil on Metabolic and Immunological Indicators of Laying Hens. Acta Vet. Brno 2008, 77: 39-44.

The metabolic and immunological indicators were determined in the blood of laying hens of ISA BROWN hybrid divided into three groups, the control group and two experimental groups. The administration of $n-3$ polyunsaturated fatty acids (PUFA) in the form of linseed (Group 1) and fish oil (Group 2) and $\alpha$-tocopherol as antioxidant to laying hens resulted in a significant increase in concentrations of high density lipoproteins (HDL) cholesterol $(P<0.05)$, eicosapentaenoic (EPA), docosahexaenoic (DHA) and $\alpha$-linolenic acids (AA) in blood in comparison to the control group. Significantly lower levels of cholesterol (CHOL) were determined in both experimental groups at the third sampling $(P<0.05)$ and arachidonic acid (AA) in the fish group $(P<0.01)$. The metabolic activity of phagocytes and polyclonal activation of lymphocytes showed no significant differences and remained within the physiological range. Oral administration of n-3 PUFA showed no significant increase of the immune response of experimental animals.
\end{abstract}

Polyunsaturated fatty acids, $\alpha$-tocopherol, cholesterol, immune response, poultry

An increasing attention has been paid to PUFA and their oxygenic derivatives, eicosanoids. An increased supply of n-3 PUFA decreases the level of triacylglycerols (TG), very low density lipoproteins (VLDL) cholesterol, CHOL and low density lipoproteins (LDL) cholesterol in blood plasma of experimental animals. In plasma lipids the proportion of EPA and DHA increases at the expense of AA. Hens fed linseed oil showed lower concentrations of VLDL, TG, glucose and CHOL (Crespo and Esteve-Garcia 2002). The mechanism of action of n-3 PUFA on plasma lipids has not been explained sufficiently. It has been assumed that n-3 PUFA decelerate the synthesis of apoprotein B (Nestel et al. 1984) or the production of VLDL, TG (Harris et al. 1984). Essential PUFA as structural components of cellular membranes and precursors of production of eicosanoids are important modulators of humoral and cell-mediated immune responses. The role of PUFA in the immune response was studied by a number of authors (Thanasak et al. 2005; Pompeia et al. 2000; Kelley 2001). The influence of PUFA depends on their concentration; low concentrations of PUFA stimulate the immune system while high concentrations have an inhibitory effect (Kelley 2001).

The aim of the experiment was to observe metabolic and immunological variables in the blood of laying hens after supplementing their diet with different ratios of linseed oil (n-6) and fish oil (n-3), and the addition of $\alpha$-tocopherol.

\section{Materials and Methods}

Animals and feeding

The experiment was carried out on clinically healthy animals - 30 laying hens of ISA BROWN hybrid, 50 weeks old, weighing 1.5 - $2 \mathrm{~kg}$. Laying hens were stabled on deep litter and group reared. Water and feed (approximately125g per hen and day) was administered to laying hens ad libitum. They were divided in three

Address for correspondence:

MVDr. Martina Švedová

Department of Chemistry, Biology and Biochemistry

University of Veterinary Medicine

Komenského 73, 04081 Košice, Slovak Republic

Phone: +421915984618

E-mail: svedova@uvm.sk

http://www.vfu.cz/acta-vet/actavet.htm 
groups, ten hens each. Layers in the first group were administered oil per os, re-calculated $3 \mathrm{~g}$ of linseed oil per $100 \mathrm{~g}$ of mixed feed. The ratio of n-6 : n-3 PUFA in the diet (mix feed and linseed oil) was $1: 1.1$. Layers in the second group were administered fish oil at a dose of $3 \mathrm{~g}$ per $100 \mathrm{~g}$ of mixed feed. The ratio of $\mathrm{n}-6: \mathrm{n}-3 \mathrm{PUFA}$ in the diet (mix feed and fish oil) was $2.7: 1$. The daily dose of linseed and fish oil per hen was $4.2 \mathrm{ml}$. In both groups $\alpha$-tocopherol was added as antioxidant. Layers in the third group (control group) received only the mixed feed "NVRM T / FAT". The ratio of n-6:n-3 PUFA in the diet (mix feed) was $9.1: 1$.

The composition of the feed "NVRM T/FAT" was: maize, wheat, soy meal, salt, limestone, feed lysine, methionine, vitamin-mineral premix (V A, E, $\left.\mathrm{B}_{2}, \mathrm{~B}_{12}, \mathrm{D}_{3}, \mathrm{Ca}, \mathrm{P}, \mathrm{Na}, \mathrm{Zn}, \mathrm{Cu}, \mathrm{Fe}, \mathrm{Mn}\right)$ and fat. The chemical composition and the content of fatty acids are shown in Tables $1-3$. The blood was sampled from vena ulnaris at the beginning of the experiment and on days 14 and 28.

Table 1. Composition of fatty acids (FA) in mixed feed (3.0\% lipids), ratio n-6 : n-3 - 9.1:1

\begin{tabular}{|lc|cc|cc|}
\hline $\begin{array}{c}\text { FA } \\
\text { designation }\end{array}$ & $\begin{array}{c}\text { Proportion } \\
\text { in } \% \\
\text { (\% of total fat) }\end{array}$ & $\begin{array}{c}\text { FA } \\
\text { designation }\end{array}$ & $\begin{array}{c}\text { Proportion } \\
\text { in } \% \\
\text { (\% of total fat })\end{array}$ & FA & $\begin{array}{c}\text { Proportion } \\
\text { in \% } \\
\text { designation } \\
\text { (\% of total fat })\end{array}$ \\
\hline C $12: 0$ & 0.168 & C $18: 0$ & 2.802 & C 20:0 & 0.465 \\
\hline C $14: 0$ & 0.865 & C $18: 1 \mathrm{n}-9$ & 27.046 & C 20:4 n-6 & 0.525 \\
\hline C $15: 0$ & 0.110 & C $18: 2 \mathrm{n}-6$ & 36.376 & C 20:5 n-3 & 0.724 \\
\hline C $16: 0$ & 24.546 & C $18: 3 \mathrm{n}-3$ & 3.029 & C 22:6 n-3 & 0.285 \\
\hline C $16: 1 \mathrm{n}-9$ & 0.406 & & & & \\
\hline
\end{tabular}

Table 2. Chemical composition of fatty acids (FA) in linseed oil, ratio n-6 : n-3 - 1:3.5

\begin{tabular}{|lc|cc|cc|}
\hline $\begin{array}{c}\text { FA } \\
\text { designation }\end{array}$ & $\begin{array}{c}\text { Proportion } \\
\text { in } \% \\
\text { (\% of total fat })\end{array}$ & $\begin{array}{c}\text { FA } \\
\text { designation }\end{array}$ & $\begin{array}{c}\text { Proportion } \\
\text { in } \% \\
(\% \text { of total fat })\end{array}$ & FA & $\begin{array}{c}\text { Proportion } \\
\text { in \% } \\
\text { designation } \\
\text { (\% of total fat })\end{array}$ \\
\hline C $12: 0$ & - & C $18: 0$ & 3.708 & C 20:0 & 0.133 \\
\hline C $14: 0$ & 0.076 & C $18: 1 \mathrm{n}-9$ & 17.791 & C 20:4 n-6 & 0.211 \\
\hline C $15: 0$ & - & C $18: 2 \mathrm{n}-6$ & 15.478 & C 20:5 n-3 & 0.227 \\
\hline C $16: 0$ & 5.347 & C $18: 3 \mathrm{n}-3$ & 53.920 & C 22:6 n-3 & 0.196 \\
\hline C $16: 1 \mathrm{n}-9$ & 0.089 & & & & \\
\hline
\end{tabular}

Table 3. Chemical composition of fatty acids (FA) in fish oil, ratio n-6:n-3 - 1:1.8

\begin{tabular}{|lc|cc|cc|}
\hline $\begin{array}{c}\text { FA } \\
\text { designation }\end{array}$ & $\begin{array}{c}\text { Proportion } \\
\text { in } \% \\
\text { (\% of total fat) }\end{array}$ & $\begin{array}{c}\text { FA } \\
\text { designation }\end{array}$ & $\begin{array}{c}\text { Proportion } \\
\text { in \% } \\
(\% \text { of total fat })\end{array}$ & $\begin{array}{c}\text { FA } \\
\text { designation }\end{array}$ & $\begin{array}{c}\text { Proportion } \\
\text { in \% } \\
(\% \text { of total fat })\end{array}$ \\
\hline C $12: 0$ & - & C $18: 0$ & 3.269 & C 20:0 & 0.250 \\
\hline C $14: 0$ & 5.684 & C $18: 1 \mathrm{n}-9$ & 18.055 & C 20:4 n-6 & 0.330 \\
\hline C $15: 0$ & 0.426 & C $18: 2 \mathrm{n}-6$ & 6.389 & C 20:5 n-3 & 4.885 \\
\hline C $16: 0$ & 16.394 & C $18: 3 \mathrm{n}-3$ & 1.419 & C 22:6 n-3 & 6.033 \\
\hline C $16: 1 \mathrm{n}-9$ & 6.521 & & & & \\
\hline
\end{tabular}

Determination of metabolic variables

The metabolic variables as CHOL and TG were determined spectrophotometrically in blood serum using BIO-LA tests (Pliva-Lachema, Brno, Czech Republic). HDL cholesterol was determined in EDTA - plasma on spectrophotometric analyser Reflotron (Boehringer Manheim, Germany). Fatty acids were determined by gas chromatography (GC) using a gas chromatograph (Carlo Erba, Milano, Italy).

Preparation of samples for GC, conditions of GC analysis

Blood serum $(0.5-1.0 \mathrm{ml})$ with $5 \mathrm{ml}$ of extraction mixture $\mathrm{CH}_{3} \mathrm{OH}: \mathrm{CHCl}_{3}(1: 2)$ were shaken for 3 min and filtered after $30 \mathrm{~min}$. One $\mathrm{ml}$ of saline $(0.9 \% \mathrm{NaCl})$ was added to the filtrate. After shaking, the mixture was allowed to stand for a minimum of $3 \mathrm{~h}$. The bottom layer was separated in a separating funnel and evaporated to dryness in a water bath at $60^{\circ} \mathrm{C}$ under nitrogen. The residue was extracted quantitatively with $3 \mathrm{ml}$ of $\mathrm{n}$-hexane which was evaporated under nitrogen and the residue was hydrolysed.

To the residue in the test tube $50 \mu \mathrm{l}$ of benzene and $2 \mathrm{ml}$ of $0.5 \mathrm{~mol} \cdot \mathrm{l}^{-1} \mathrm{KOH}$ in ethanol-water mixture $(9: 1)$ were added and mixed with a mixer. The closed test tube was mixed and then allowed to hydrolyse at $80{ }^{\circ} \mathrm{C}$ for $1 \mathrm{~h}$. After cooling to laboratory temperature, $0.5 \mathrm{ml}$ distilled water was added and mixed again. After adding 
$3 \mathrm{ml} \mathrm{n}$-hexane, the hydrolysed lipids were extracted for $5 \mathrm{~min}$ by shaking and then were centrifuged for $5 \mathrm{~min}$ at $5300 \mathrm{~g}$. After the removal of the upper hexane layer, the bottom layer was re-extracted with additional $3 \mathrm{ml}$ of $\mathrm{n}$ hexane, acidified with $0.35 \mathrm{ml} 3 \mathrm{~mol} \cdot \mathrm{l}^{-1} \mathrm{HCl}$ and mixed. Five $\mathrm{ml}$ of $\mathrm{n}$-hexane were added, and after extraction the mixture was centrifuged. The upper extraction phases were transferred to a tube with a Teflon stopper, n-hexane was evaporated under nitrogen, the dry residuum was dissolved in $1 \mathrm{ml}$ of hexane and $0.1 \mathrm{ml}$ of trans-esterificating reagent was added. The mixture was mixed by shaking. After $20 \mathrm{~min}$ a red layer of reagent sedimented. After $45 \mathrm{~min}$ the upper hexane layer was transferred to a clean tube and hexane was evaporated under nitrogen. The residue was dissolved in $100 \mu \mathrm{l}$ hexane and $2 \mu \mathrm{l}$ of sample were injected onto a GC column. The capillary used for analyses was $30 \mathrm{~m}$ long (ZB-WAX), internal diameter $0.53 \mathrm{~mm}$. The stationary phase - polyethyleneglycol, pressure of the carrier gas $0.8 .10^{5} \mathrm{~Pa}$, flow rate of hydrogen $28 \mathrm{~cm}^{3} \cdot \mathrm{min}^{-1}$ and of air $500 \mathrm{~cm}^{3} \cdot \mathrm{min}^{-1}$, detector temperature $250{ }^{\circ} \mathrm{C}$, temperature of the working flow-through column $180^{\circ} \mathrm{C}$. A flame-ionization detector (FID) was used. The computer software APEX - CSW1.7 was used for integration.

Determination of immunological indicators

An iodo-nitro-tetrazolium reductase test (Lokaj and Oburkova 1975) was used to evaluate the functional activity of phagocytes in the peripheral blood of laying hens. The functional activity of lymphocytes was determined on the basis of mitogenic activation of lymphocytes with phytohaemagglutinin (PHA, Sigma) in a migration-inhibition test (MIT) under agarose (Bendixen et al. 1976). Results were evaluated statistically using the ANOVA test.

\section{Results}

Results of analyses of metabolic and immunological variables in laying hens are presented in Figs 1 - 6. At the first sampling, CHOL levels varied considerably (Fig. 1). At the second sampling, we observed a significant decrease in the group administered fish oil $(P<0.05)$. At the third sampling, CHOL levels in both experimental groups were significantly lower $(P<0.05)$ compared to control hens. At the beginning of the experiment the plasma level of HDL cholesterol showed considerable variations (Fig. 2). The highest level was observed in the control group which differed significantly $(P<0.05)$ from the group administered fish oil. Additional samplings showed a marked increase in the fish group and the concentrations measured differed significantly from the control and also from the initial values $(P<0.05)$. HDL cholesterol in the linseed group remained almost on the same level throughout the experiment. The results at second and third samplings in the group supplemented with linseed oil were significantly higher $(P<0.05)$ in comparison with the control. Concentrations of TG in experimental groups at first sampling were lower in comparison with the control fed only the base diet. At the second sampling, we observed a significant decrease $(P<0.05)$ in the level of TG in the fish group and an increase in the linseed group in comparison with the control. At the third sampling, a significant increase $(P<0.05)$ in the TG concentration was observed in the groups supplemented with fish oil and an increase in the linseed group compared to the control which was also reflected in their body weight. Fig. 4 shows concentrations of PUFA in the blood serum of hens determined at second sampling. It indicates that the diets with a higher concentration of n-3 acids affected markedly their concentrations in blood. A highly significant increase was observed in the levels of $\alpha$-linolenic acid, particularly in the group supplemented with linseed oil. This is understandable because linseed oil contains up to $54 \%$ of this acid. With regard to other n-3 PUFA (EPA, DHA), significantly higher $(P<0.01)$ concentrations were observed in the group supplemented with fish oil, with the lowest concentration of AA $(P<0.01)$ in comparison with the control, while the group supplemented with linseed oil showed significantly lower results compared to the control.

The results of immunological variables are shown in Figs 5 and 6. Evaluation of polyclonal activation of lymphocytes by mitogen (PHA) showed no marked differences in mean values of the migration index $(\mathrm{MI})$ between experimental groups and the control. MI was within the reference range $(\mathrm{MI}<0.8)$ in all the groups. Experimental groups exhibited non-significantly higher values in comparison with the control. However, at the end of the experiment, MI values in all three groups were very close. The index of metabolic activity (IMA) of phagocytes, which indicates enzymatic activity of phagocytes under 


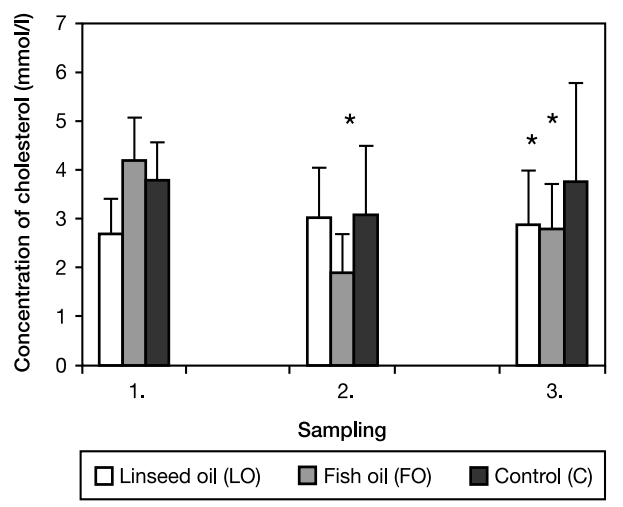

Fig. 1. Concentration of cholesterol in the blood serum of laying hens after administration of oils containing n-acids $\left(P<0.05^{*}\right)$

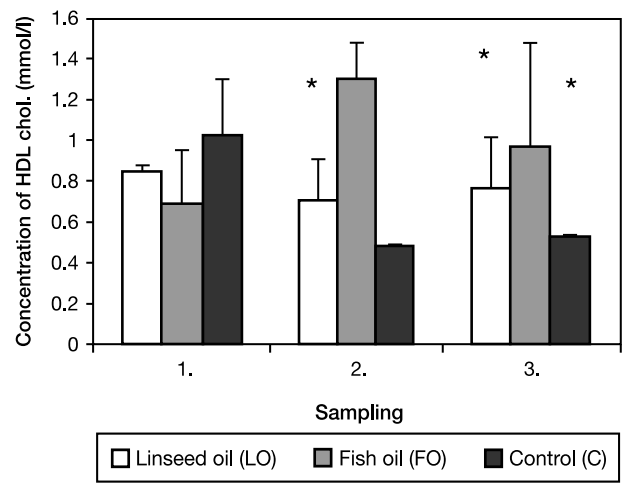

Fig. 2. Concentration of HDL cholesterol in the blood plasma of laying hens after administration of oils with higher content of n-acids $\left(P<0.05^{*}\right)$

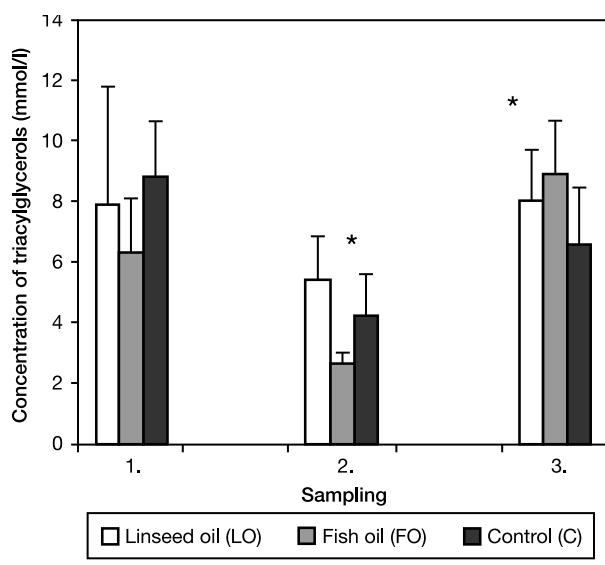

Fig. 3. Concentration of triacylglycerols in the blood serum of laying hens after administration of oils containing n-acids $\left(P<0.05^{*}\right)$ a load, corresponded to the physiological limit in all hens at all samplings. While one week after the beginning of the experiment ( $2^{\text {nd }}$ sampling) only the group with fish oil showed non-significantly higher values, at the third sampling the values in both experimental groups were non-significantly higher in comparison with the control, which indicated more intensive metabolic activity of phagocytes.

\section{Discussion}

The results of our experiment indicated that diets with a higher content of n-3 PUFA affected the indicators observed in the blood of hens. The most pronounced changes were observed in the level of PUFA. Our measurements showed a marked increase in n-3 FA (ALA, EPA, DHA). The results are in agreement with literary data reported in chickens (Newman et al. 2002). Comparison of levels of individual PUFA in blood and feed showed rather remarkable differences. We expected relatively high levels of ALA in the blood of hens fed linseed oil containing a high proportion of this acid (54\%), which constitutes an almost exclusive source of n-3 PUFA. Very high levels of ALA were observed in the group of hens supplied fish oil with a low content of this acid (1.4\%). It may be assumed that ALA occurs in the organism as a product of degradation of EPA and DHA used as energy sources. High levels of EPA and DHA in the group of hens supplemented with fish oil reflected a higher content of these FA in the fish oil itself. The contents of EPA and particularly DHA in experimental hens from the fish oil group were higher in comparison with the control. This suggested that the respective acids were synthesised in the body from ALA. The most frequently reported physiological ratio of n-6 and n-3 PUFA in the feed ranged between $10: 1$ and $4: 1$. We consider this ratio as informative. It should be important to determine the content and ratio of individual PUFA within the n-3 series. Will the synthesis of EPA and DHA suffice when ALA will serve as the only source of $n-3$ ? This remains apparently an open question as individual animal species 
react differently to an increased intake of n-3 PUFA. Our results obtained in the group supplemented with fish oil agree with those reported by Noble and Cocchi (1990). The present investigations proved that fish oil has a more pronounced effect than linseed oil and that supplementation of n-3 PUFA can alter composition of fat in poultry products. It is obvious that the increased intake of n-3 PUFA will affect also other lipid variables with decreasing $\mathrm{CHOL}$ and $\mathrm{TG}$ and increasing HDL cholesterol (Crespo and EsteveGarcia 2002). This was confirmed also by our results. The egg yield during the whole experiment was very close. The egg yield at the second sampling was the highest in both experimental groups in comparison with the control group. The groups supplemented with linseed oil showed a decrease in the egg yield starting from the second sampling, but the average weight of eggs was higher at the end of the experiment in comparison with the control group. The role of PUFA in the immune response was studied by a number of authors (Thanasak et al. 2005; Kelley 2001). The results obtained in our experiment did not differ significantly from the controls but the increased levels of the observed variables could be evaluated as positive.

\section{Vplyv l'anového a rybieho oleja na metabolické a imunologické ukazovatele nosníc}

Metabolické a imunologické ukazovatele boli stanovené v krvi nosníc ISA BROWN hybrid, ktoré boli rozdelené do troch skupín, kontrolná skupina a dve experimentálne skupiny. Podávaním n-3 PNMK v l'anovom a rybom oleji a $\alpha$-tokoferolu ako antioxidantu sa signifikantne zvýšili koncentrácie HDL cholesterolu $(P<0,05)$, kyseliny eikozapentaénovej (EPA), dokozahexaénovej (DHA) a $\alpha$-linolénovej (AA) v krvi pokusných nosníc oproti kontrole. Statisticky nižšie hladiny cholesterolu (CHOL) boli stanovené v tret'om odbere u oboch pokusnych skupín $(P<0,05)$ a kyseliny arachidonovej (AA) u skupiny suplementovanej rybím olejom $(P<0,01)$. Metabolická aktivita fagocytov ako aj polyklonálna aktivácia lymfocytov nevykazovala signifikantné rozdiely, pohybovala sa vo fyziolo-

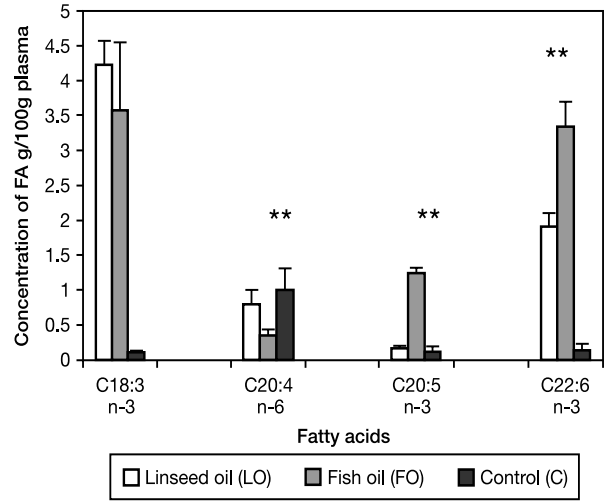

Fig. 4. Concentration of fatty acids in the blood serum of laying hens supplemented with oils containing n-3 acids, determined 2 weeks after the beginning of the experiment $(P<0.01 * *)$

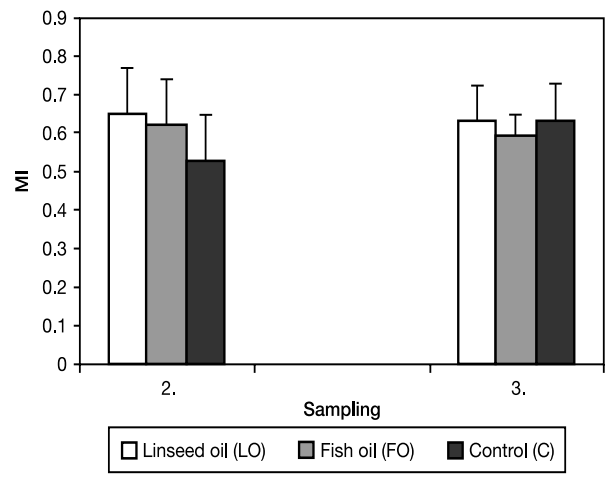

Fig. 5. Index of migration of lymphocytes in peripheral blood of hens after administration of oils with higher content of n-3 acids

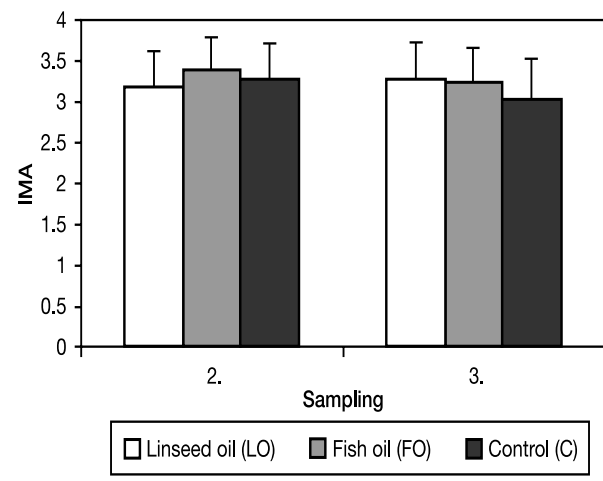

Fig. 6. Index of metabolic activity of phagocytes in peripheral blood of laying hens after administration of oils with higher content of n-3 acids 
gickom rozhraní. Perorálne podávanie n-3 PNMK mierne zvyšovalo imunitnú odozvu organizmu experimentálnych zvierat.

\section{Acknowledgement}

This work was supported by the Scientific Grant Agency of the Slovak Republic - VEGA (Grant No. $1 / 9013 / 02)$

\section{References}

BENDIXEN G, BENDTZEN K, CLAUSEN JE, KJAER M, SOBORG M 1976: Human leukocyte migration inhibition. Scand J Immunol 5: 175-184

CRESPO N, ESTEVE-GARCIA E 2002: Nutrient and fatty acid deposition in broilers fed different dietary fatty acid profiles. Poult Sci 81: 1533-1542

HARRIS WS, CONNOR WE, INKELES SB, ILLINGWORTH DR 1984: Dietary omega-3 fatty acids prevent carbohydrate-induced hypertriglyceridemia. Metabolism 33: 1016-1019

KELLEY DS 2001: Modulation of human immune and inflammatory responses by dietary fatty acids. Workshop: Anorexia during disease - from research to clinical practice. Nutrition 17: 669-673

LOKAJ V, OBURKOVA P 1975: Estimation of tetrazolium-reductase activity of leukocytes. (In Czech) Imunol Zprav 6: $42-44$

NESTEL PJ, CONNOR WE, REARDON MF, CONNOR S, WONG S, BOSTON R 1984: Suppression by diets rich in fish oil of very low density lipoprotein production in man. J Clin Invest 74: 72-89

NEWMAN RE, BRYDEN WL, FLECK E, ASHES JR, STORLIEN LH, DOWNING JA 2002: Dietary n-3 and $\mathrm{n}-6$ fatty acids alter avian metabolism: 11. Molecular-species composition of breast muscle phospholipids. $\mathrm{Br}$ J Nutr 88: 19-28

NOBLE RC, COCCHI M 1990: Lipid metabolism and the neonatal chicken. Prog Lipid Res 29: 107-140

POMPEIA C, LOPES LR, MIYASAKA CK, PROCOPIO J, SANNOMIYA P, CURI R 2000: Effect of fatty acids on leukocyte function. Brazilian J Med Biol Res 33: 1255-1268

THANASAK J, MÜLLER KE, DIELEMAN SJ, HOEK A, NOORDHUIZEN JPTM, RUTTEN VPMG 2005: Effects of polyunsaturated fatty acids on the proliferation of mitogen stimulated bovine peripheral blood mononuclear cells. Vet Immunol Immunopathol 104: 289-295 